Florida International University FIU Digital Commons

\title{
The Real Snowbirds of South Florida: Using Citizen Science to Assess the Ranges of South Florida's Overwintering Birdsh
}

Alexander V. Levine

Florida International University, alevi034@fiu.edu

DOI: $10.25148 /$ etd.FIDC006866

Follow this and additional works at: https:// digitalcommons.fiu.edu/etd

Part of the Biodiversity Commons, Ornithology Commons, and the Population Biology Commons

\section{Recommended Citation}

Levine, Alexander V., "The Real Snowbirds of South Florida: Using Citizen Science to Assess the Ranges of South Florida's Overwintering Birdsh" (2018). FIU Electronic Theses and Dissertations. 3769.

https://digitalcommons.fiu.edu/etd/3769 
FLORIDA INTERNATIONAL UNIVERSITY

Miami, Florida

THE REAL SNOWBIRDS OF SOUTH FLORIDA:

USING CITIZEN SCIENCE TO ASSESS THE RANGES OF

SOUTH FLORIDA'S OVERWINTERING BIRDS

A thesis submitted in partial fulfillment of the

requirements for the degree of

MASTER OF SCIENCE

in

BIOLOGY

by

Alexander Levine

2018 
To: Dean Michael R. Heithaus

College of Arts, Sciences, and Education

This thesis, written by Alexander Levine, and entitled The Real Snowbirds of South Florida: Using Citizen Science to Assess the Ranges of South Florida's Overwintering Birds, having been approved in respect to style and intellectual content, is referred to you for judgement.

We have read this thesis and recommend that it be approved

$\begin{array}{r}\hline \text { Sparkle Malone } \\ \hline \text { Steven Oberbauer, Co-Major Professor } \\ \hline \text { Maureen A. Donnelly, Co-Major Professor }\end{array}$

Date of Defense: June 27, 2018

The thesis of Alexander Levine is approved

Dean Michael R. Heithaus
College of Arts, Sciences and Education

Andres Gil

Vice President for Research and Economic Development And Dean of the University Graduate School

Florida International University, 2018 


\section{ACKNOWLEDGMENTS}

I wish to thank the members of my committee for their unerring support and guidance. Dr. Donnelly and Dr. Oberbauer adopted me when I lost my advisor and helped me forge a new path forward. Dr. Malone showed me the light at the end of the tunnel when my confidence began to flag. Thank you to Fairchild Tropical Botanic Garden for the Graduate Fellowship that financed my graduate degree and afforded me experiences that led to the career of my dreams. The Fairchild Education Department has been a pleasure to work with. Finally, thanks to my husband, Philip Buchanan, without whose support none of this would have been possible. 


\section{ABSTRACT OF THE THESIS \\ THE REAL SNOWBIRDS OF SOUTH FLORIDA: USING CITIZEN SCIENCE TO ASSESS THE RANGES OF SOUTH FLORIDA'S OVERWINTERING BIRDS}

\section{By}

Alexander Levine

Florida International University, 2018

Miami, Florida

\section{Professor Maureen A. Donnelly, Co-Major Professor \\ Professor Steven Oberbauer, Co-Major Professor}

The overwintering ranges of North American bird populations are shifting and the winter ranges of south Florida's landbirds remain understudied. Expertdrawn range maps used for scientific studies and environmental public policy could therefore be depicting inaccurate ranges for many migratory birds. This study used citizen science data from eBird (2001-2017) to evaluate patterns in overwintering avian species richness and identify discrepancies in expert-drawn species range maps for overwintering passerines in south Florida. Most of Florida's overwintering bird species were sighted in south Florida. Of the species observed there between 2001 and 2017, 66\% had range map discrepancies. Fifteen target species were examined in the present study and fourteen of them were sighted in south Florida throughout the winter. None of these were depicted on range maps as overwinterers. These results showed that current expertdrawn range maps likely misrepresent the current winter ranges of passerine species in south Florida. 


\section{TABLE OF CONTENTS}

CHAPTER

PAGE

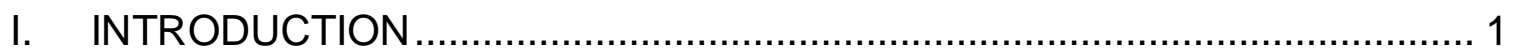

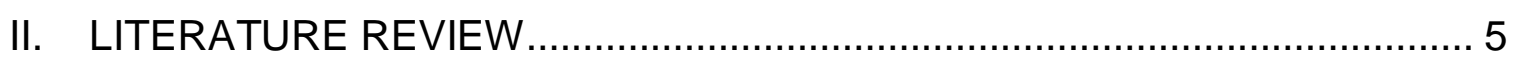

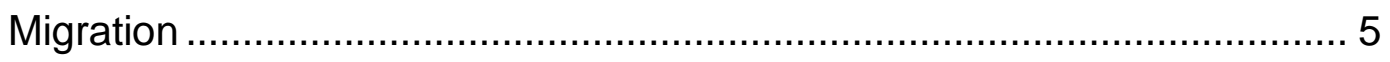

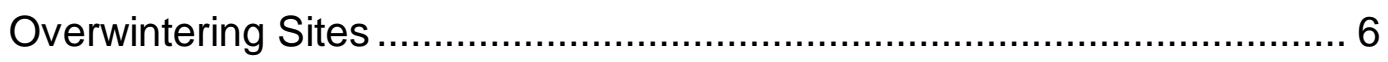

Florida and Species Richness …....................................................... 7

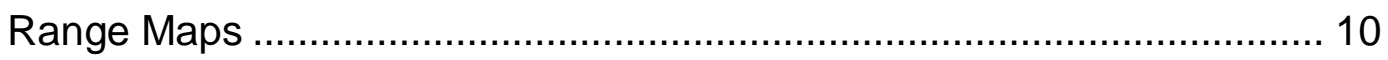

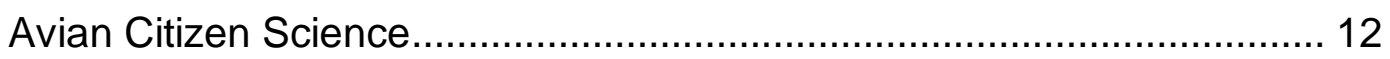

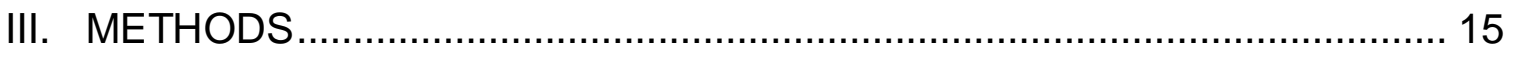

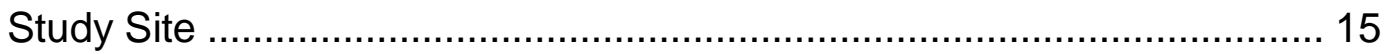

Patterns in Overwintering Passerine Richness ...................................... 16

Choosing Target Species ................................................................. 16

Evaluating Expert-drawn Range Map Discrepancies.............................. 17

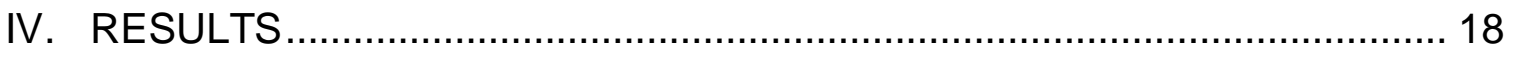

Patterns in Overwintering Songbird Richness ........................................ 18

Expert-drawn Range Map Discrepancies .............................................. 19

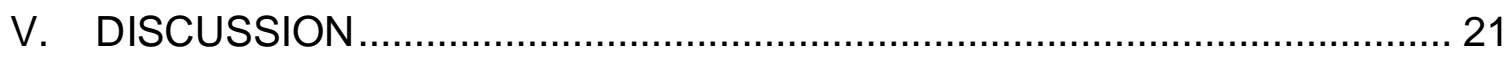

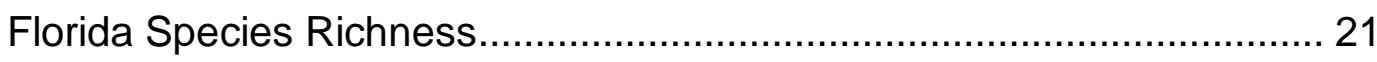

South Florida Species Richness ....................................................... 23

Expert-drawn Range Map Discrepancies .............................................. 24

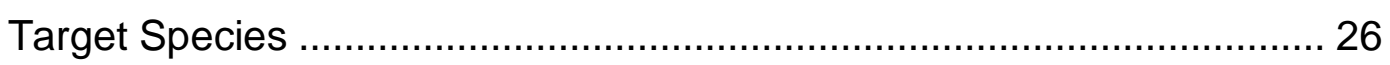

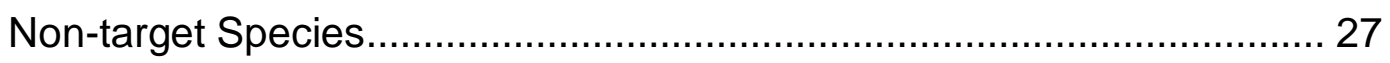

VII. FUTURE RESEARCH AND CONCLUSION ............................................. 28

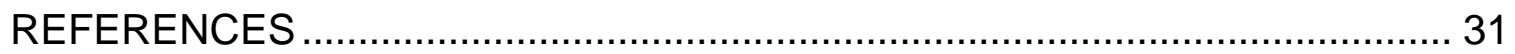

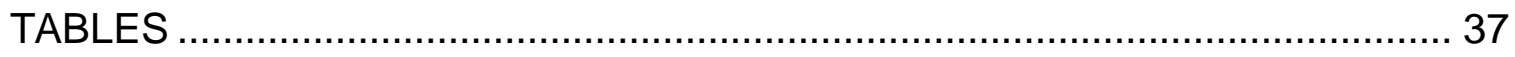


FIGURES... 


\section{LIST OF TABLES}

TABLE

PAGE

1. Target Species Sightings Ranks and Range Map Statuses....................37 


\section{LIST OF FIGURES}

FIGURE

PAGE

1. Florida's Winter Avian Species Richness and Frequency.......................38

2. Temporal Changes in Species Richness ....................................39

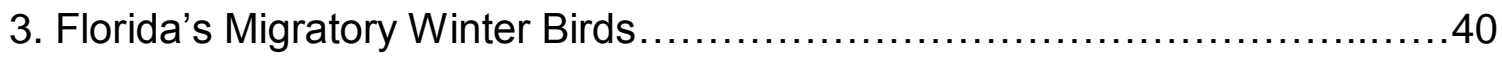

4. South Florida's Migratory Winter Passerines...............................41

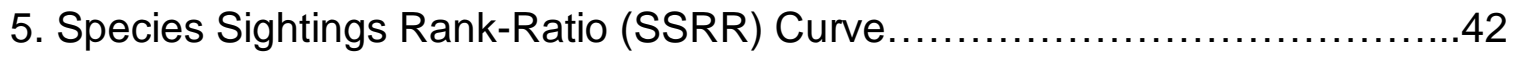

6. Target Species Sightings Ratios ...........................................43

7. Target Species Sightings Maps ........................................... 44 


\section{!. INTRODUCTION}

With over 10,000 species occupying every terrestrial and most aquatic environments, birds are one of the most-studied group of organisms on the planet. By engaging in spectacular long-distance seasonal migrations, many birds exemplify how global ecosystems are biologically integrated. Additionally, changes in avian populations often indicate shifts in ecosystem health or processes (Sullivan et al., 2009). Over the last century, climate and land-use changes have been the two major drivers of avian population declines. Because migratory birds occur in a variety of geographic regions throughout the year, a single species can be an indicator of these changes over wide temporal and geographic scales (La Sorte et al., 2017).

Studies suggest that by 2080 , the size and location of non-breeding and breeding ranges of birds in North America are likely to dramatically shift, with different areas projected to gain and lose species in varying ratios depending upon the season (Princè \& Zuckerberg, 2015). Whereas peak areas of predicted loss during the breeding season are primarily at high elevations and latitudes, low latitude coastal states like Florida are likely to have the highest levels of nonbreeding season species loss. Examining the ranges of individual species in under-studied areas like south Florida can help predict these changes (Langham et al., 2015).

There is little information regarding overwintering birds in Florida despite high overwintering species richness in the southeastern United States 
(Somershoe et al., 2009). Studying overwintering birds is particularly crucial because overwintering is now widely viewed to have the greatest impact on fitness and reproductive success (Mith et al., 2010). With global changes continuing to negatively impact migratory birds, understanding when overwintering birds are present and where they occur can fill a gap in avian research and inform the development of songbird conservation strategies (Somershoe et al., 2009).

Expert-drawn range maps, commonly used in avian studies and field guides, estimate where avian species occur by encompassing known presences within a continuous area. Despite their shortcomings, range maps are vital for establishing the extent of avian species' ranges in each part of their annual cycle (Barbosa et al., 2012). These maps are currently the primary source of information regarding where migratory birds are found and have already played a large role in recent studies on global climate and land-use impacts. With few exceptions, however, assessments of anthropogenically-driven bird population declines have focused upon summer breeding ground occurrence and ecology. Studies of avian overwintering remain woefully under-represented despite the fact that it is critical to the relatively compressed breeding season (La Sorte et al., 2017).

Our knowledge of avian distribution patterns remains limited, with most current expert range maps too coarse and uneven to support biodiversity science requirements for thousands of species (Merow et al., 2016). Understanding the extent of a species' range allows scientists to address conservation issues, land 
management plans, the consequences of global climate change, and a variety of ecological and evolutionary problems across broad areas. Accurate assessments of species' distributions and changes in range are vital variables that need to be quantified to monitor and improve our understanding of global biodiversity (Amano et al., 2016). If a species' current range assessment can be shown to be inaccurate or lacking, it represents a significant knowledge gap for future ecological, biodiversity, or conservation planning (Merow et al., 2017).

Examining the ranges of migratory species is a key element for determining the effects of humans on nature. Migratory birds are effective indicators of broad-scale environmental changes and are one of the world's most widely monitored taxa. Beautiful, charismatic, and often easy to observe, birds are a favorite subject of amateur naturalists. Their citizen science observations are an increasingly important tool for analyzing temporal and spatial patterns of avian populations (Amano et al., 2016). Data from citizen scientists' sightings can now be collected and vetted on a vast scale using eBird online, a collaborative initiative between the Cornell Lab of Ornithology and the National Audubon Society (Sullivan et al., 2009). Constantly updated in real-time and with millions of data points available, eBird's voluntarily-collected citizen science data can be used to compliment standardized surveys and expert-drawn range maps (Amano et al., 2015).

Despite containing vital and unique habitats for many species of Neotropical-Nearctic migratory birds, south Florida is often overlooked in landbird research. With a high number of migratory, endemic, and threatened bird 
species, a lack of studies about avian ranges within Florida represents a major knowledge gap (Benscoter et al., 2013). My study uses eBird data to determine if expert-drawn range maps for fifteen species of songbirds are accurate.

Specifically, I will (1) evaluate patterns in overwintering songbird richness and (2) identify discrepancies in expert-drawn species range maps for passerines that overwinter in the state's ten southernmost counties comprising south Florida Broward, Charlotte, Collier, Glades, Hendry, Lee, Martin, Miami-Dade, Monroe, and Palm Beach.

This project was conceived after spending several weeks in the field each winter for three years casually observing birds in Miami-Dade County and crossreferencing eBird sighting frequency histograms on the eBird-sourced BirdsEye smartphone application. After noting that these histograms did not depict several observed species as overwintering in south Florida, I began to compare current expert-drawn range maps from the National Audubon Society (Audubon), Cornell Lab of Ornithology (Cornell), and NatureServe with eBird's Miami-Dade County histograms over the past two years.

Nineteen species were identified that were seen in south Florida during the winter (December 21-March 21) but were not listed as overwintering throughout south Florida on all three range maps. These species were crossreferenced with 30 years of Christmas Bird Count (CBC) data and a final sample group of 15 migratory passerine birds was compiled after four nonmigratory species were excluded. The null hypothesis for this study states that the expertdrawn range maps for these 15 avian species are consistent with eBird data. 


\section{LITERATURE REVIEW}

\section{$\underline{\text { Migration }}$}

Migration - the movement of individuals between habitats - is a common adaptation in animals living in seasonal habitats with temporally fluctuating food sources (Hedenstrom, 2008). Migratory North American-breeding birds generally fly south to escape harsh conditions and dwindling food supplies. After taking advantage of favorable climates and resources in overwintering grounds, birds fly back north to feed on seasonally-abundant food sources, establish territories, reproduce, and rear broods. These journeys have proven evolutionarily advantageous despite their high costs (Sibley et al., 2013).

Approximately $75 \%$ of the nearly 700 species of birds nesting in North America are migratory with members of nearly all North American avian families wintering south of the United States (Sibley et al., 2013). Most of North America is considered the Nearctic; southern Mexico, the Caribbean, Central America, and South America are the Neotropics. Some breeding birds in temperate parts of South America migrate north to overwinter, but these species are very rarely found in North America. Birds that migrate entirely within South and Central America are correctly called "Neotropical migrants," but this term is usually applied to the nearly-400 species breeding in North America and migrating south for the winter. These species are more accurately called "Nearctic-Neotropical" migrants (Hayes, 1995).

North American landbirds primarily use four major migratory flywaysPacific, Central, Mississippi, and Atlantic. All four major flyways vary in their 
geographic locations between migratory seasons, with the Atlantic flyway appearing to be strongly influenced by the Great Plains' low-level jetstream providing tailwinds during spring migration (FFWC, 2014). Broad-scale environmental changes that affect atmospheric conditions could already be influencing migratory paths, potentially shifting the locations of stopover and overwintering sites (La Sorte et al., 2014).

$\underline{\text { Overwintering Sites }}$

Before the 1970s, studies on migratory Nearctic-Neotropical landbirds focused almost entirely on their breeding season, virtually ignoring their nonbreeding ecology. Any conservation concerns were focused upon breeding habitats and reproductive success. A major shift in avian research occurred in 1977 at the Smithsonian symposium, "Migrant birds in the Neotropics: ecology, behavior, distribution, and conservation." One of the main points of discussion was that many birds spent much more time overwintering in the tropics than they did on their breeding grounds. Additionally, many of these birds depended upon specific winter habitats, played integral roles in tropical bird communities, and displayed winter-site fidelity (Keast \& Morton, 1977). Since this symposium, the standard model of migration shifted from one depicting largely temperate birds traveling to the tropics to escape harsh winters, to one of birds that originated in the tropics and evolved to use resources in the temperate zone to increase reproductive success (Faaborg et al., 2010). Studies have since reflected that population limitations occur on different temporal and spatial scales and that understanding habitat usage during all phases of the avian lifecycle is necessary 
to manage migratory species (Latta \& Faaaborg, 2009).

Still, relatively few papers about the overwintering ecology of migratory birds have been published. Many of these species spend their winters in mixed flocks-groups of different species cohabitating in what are often much smaller territories than those established in the summer breeding season. Because birds that breed in vast North American expanses typically winter in these highlypopulated tropical areas, losing a single acre of winter habitat could deplete five to eight temperate acres of its migrant birds (Faaborg et al., 2010). Any avian conservation efforts must therefore be derived from an understanding of how and where migratory birds overwinter and what factors are affecting bird populations on these overwintering grounds.

\section{Florida and Species Richness}

Florida is home to a large and diverse number of birds. With the Atlantic and Mississippi flyways converging over the state, many of its native species are migrants (FFWC, 2014). A hotspot of species richness, endemism, and vital habitats for migratory birds, Florida is of particular significance to conservationists. Only Hawaii, California, and Alabama have more federally endangered species, and ten percent of all federally endangered taxa occur in Florida (Benscoter et al., 2013).

Species richness is often used as an ecological indicator, as well as a criterion for biodiversity planning and conservation. Spatially and temporally variable, species richness often increases as latitudes decrease. This latitudinal gradient for species diversity (LGSD) is broadly supported by the "energy 
hypothesis" which proposes that diversity is limited by available water and energy (Hawkins et al., 2014). Although average annual productivity has been shown to increase close to the equator, summer production shows virtually no relationship with latitude in seasonal areas (Hurlbert \& Haskell, 2003). A lack of variation in productivity could help explain why south Florida, with minimal seasonal changes in weather, seems to defy latitudinal species richness trends seen elsewhere in North America (Hawkins et al., 2014). South Florida's high arthropod abundance could also contribute to its ability to support many species of largely insectivorous birds (Peck, 1989). However, no studies have directly examined species richness in south Florida's overwintering migratory species.

Peninsular geography is theorized to increase the probability of extinction by hindering immigration, thus causing a reduction in species diversity as you travel away from the base of any peninsula (Wiggins, 2013). This peninsula effect is primarily observed in terrestrial mammal and herpetofauna populations, although it has been observed with varying effect in different bird communities (Jo et al., 2017). Many avian studies have, however, found that species richness often does not decline as you approach the tip of a peninsula. While immigrationextinction dynamics might explain some peninsular patterns of species richness, others show a stronger correlation between species richness and changes in habitat heterogeneity as the distal part of a peninsula is approached (Wiggins, 2013). In oceanic peninsulas, immigration from nearby islands can also affect richness (Tubelis et al., 2007). 
Neotropical avian species richness is directly linked to habitat diversity and topographic heterogeneity. Areas with homogeneous habitats reliably contain fewer bird species than more heterogeneous ones (Rahbek \& Graves, 2001). Topographic homogeneity can be a particularly important predictor of less-common species' rarity (Jetz \& Rahbek, 2002). Florida's relatively homogeneous landscape could therefore be a limiting factor for avian species richness.

There is generally a strong linear relationship between the structure and volume of native plants and avian species richness. However, as the number of non-native plant species increases, native avian species richness tends to decline. Often the composition of urban and suburban bird communities includes a small number generalist non-native species (Chace \& Walsh, 2006). Florida is particularly vulnerable to the effects of non-native plants, as it contains nearly 1,000 non-indigenous naturalized plant species. Almost one third of Florida plant species $(27 \%)$ are non-natives (Gordon, 1998). In the Everglades alone, there are approximately 170 non-native plant species, with five of these establishing dominance in several natural areas (Rodgers et al., 2018).

A particular species-area effect is created by urbanization, where an increase in large expanses of impervious surfaces fragments and limits suitable habitats for wildlife. While the structural simplification of urban plant communities can negatively impact biodiversity, this is sometimes countered by an increase in spatial habitat heterogeneity caused by a wide range of land uses and cultivated plants (Marzluff \& Ewing, 2001). These urban areas can also boast increased 
primary production because of abundant water and the use of fertilizers (Adams, 1994). However, native avian species richness has been shown to broadly decrease with urbanization; a few avian species, often introduced, dominate many urban bird communities. These areas also tend to favor residential species over migrants which increases avian biomass while reducing overall species richness (McKinney, 2008). As urbanization rises, anthropogenic changes in land cover will increasingly alter ecosystem processes and patterns while human population pressures will continue to stress natural areas. Examining avian ranges provides vital baseline information for managing a highly urbanized landscape.

\section{Range Maps}

A variety of studies in biology, ecology and conservation rely upon current data regarding the distribution of species. These data are used to identify critical conservation areas, to analyze how and why certain occurrence and trait patterns occur, and to identify threats to individual species (Cantù-Salazar \& Gaston, 2013). Two components are used when defining a species' geographic range: extent of occurrence and area of occupancy. Extent of occurrence is defined by the outermost geographic points inside of which a species can be found. Area of occupancy is the area where the target species actually occurs within the extent of occurrence, though a species' geographic range is generally defined by extent of occurrence (La Sorte \& Hawkins, 2007).

Expert-drawn range maps are the de facto source of data to analyze species distributions over broad geographical extents, although no single 
standardized method is used to approximate range boundaries or extents of occurrence (Habib et al., 2003). These maps, commonly used in avian studies and field guides, are constructed by connecting the outermost points representing locales where a species has been recorded, primarily through surveys and historical records. The continuous area within these points is considered the expert-drawn species range. Individuals are, however, not found everywhere within this range; such maps can create false presences when uniform occurrence is assumed throughout a particular area (Barbosa et al., 2012). When range maps are derived from historical records primarily taken from collected specimens and museum archives, the discrepancy between the reported range of a species and its actual area of occupancy can be particularly significant (Habib et al., 2003).

While existing expert-drawn range maps can provide useful guidelines about species' ranges, these maps typically have overly-generous extents, appearing as large contiguous patches that often over-predict presences at small resolutions or under-predict presences outside of the official range boundary. Species could therefore be absent in different regions within these range maps and be present outside of it. These range mismatches become more likely with migratory species, where expert-drawn range maps, often updated with new information after long intervals, miss disjunct or new parts of a distribution. Range maps illustrating incomplete distributions could be addressed by incorporating current citizen science data (Merow et al., 2017). 


\section{$\underline{\text { Avian Citizen Science }}$}

Everyday citizens have observed and studied birds for hundreds of years, with amateur ornithologists greatly contributing to the advancement of the field. Tens of thousands of amateur participants in such citizen science efforts as the National Audubon Society CBC and the North American Breeding Bird Survey (BBS) have helped to identify avian population trends over many decades. With the advent of the Internet making the real-time exchange of information to a vast audience possible, data gathering efforts can now be made on an exceedingly broad scale (Sullivan et al., 2009).

Large-scale, long-term citizen science monitoring studies have long provided critical data on avian populations for a variety of management and conservation activities. Before the advent of the internet, the primary source of information about North American landbird population trends was the North American BBS, a monitoring program performed primarily by volunteers and administered by the Canadian Wildlife Service (CWS) and the U.S. National Biological Service (USNBS). However, because the BBS focuses on a single time period in the avian life cycle, using it alone for population estimates is problematic. Combining summer-sourced BBS data with information collected from the winter CBC was an attempt to address this issue (Thomas \& Martin, 1996).

While the BBS and CBC continue to bolster long-term data about North American birds, eBird has since become one of the premiere avian citizen science efforts. Launched in 2002 by the Cornell Lab of Ornithology and the 
National Audubon Society, eBird uses standardized protocols to engage thousands of citizen-scientist observers who report bird sightings using their personal computers and mobile devices (CLO, 2018). The observations eBird gathers, organizes, and disseminates data about migratory timing, species occurrences, and relative abundance at different temporal and spatial scales. The eBird project also maintains a permanent repository for observations and gives each user a way to track their personal sightings and keep ongoing bird lists (Sullivan et al., 2009). With over 19 million checklists from across the world, including more than 17 million from North America alone, eBird's aggregation of avian sightings has been extensively used in many contemporary avian studies. Although the majority of eBird sightings are from the past decade, historical checklists containing dates and specific locations have been entered and archived along with current data (CLO, 2018). Containing sightings from throughout the year and over a vast geographic range, eBird can be used to fill data gaps left by the BBS and CBC (Walker \& Taylor, 2017).

Citizen science sightings such as those found on eBird are considered point-occurrence or presence-only $(\mathrm{PO})$ data. False presences in PO data are low, arising only from identification errors. However, using this information alone is problematic as a result of the potentially non-representative nature of PO data stemming from different forms of sampling biases (Merow et al., 2017). Therefore, integrating expert-drawn maps with PO data is potentially an ideal way to improve estimates of the ranges of species. Efforts to combine the two using spatial offsets in regression models have shown promising results, taking 
advantage of the different data types' strengths to improve species' distribution predictions (Merow et al., 2017). Identifying which range maps should be reexamined and compared to current PO data is a vital first step in this process.

Survey-based eBird data have their own constraints, such as biases toward accessible locations, differences in survey effort, and problems detecting species that are difficult to see or have low rates of occurrence (Cantù-Salazar \& Gaston, 2013). In general, citizen science data are vulnerable to certain biases and errors including: 1) varying probabilities of reporting observations for different species, 2) varying search effort and detectability between species and years, 3) non-random choice of localities, and 4) varying citizen scientist skills. Sometimes the most common species are not reported by experienced birders, so an absence of reports should not automatically be equated to an absence of individuals (Amano et al., 2015). While eBird encourages the use of full checklists to resolve this type of problem, these errors could still be present on some lists. Because search effort and species detectability affect the probability of seeing different species, effort is reported and standardized in citizen science databases like eBird. However, the type of lists individual birders keep can affect their willingness to report certain observations. For example, "twitchers" will sometimes only report the species they are seeking out on that occasion (Amano et al., 2015).

The eBird project has developed methods to help ensure basic data quality standards for submissions. Before a checklist will be accepted into the eBird database, all observation process data - the date, who the observer is, the 
location of the observations, species counts, duration of birdwatching, distance traveled, number of people in the party, and if it is a full or partial species list -

must be entered. All reported species then pass through automated data quality filters that use expert opinions and historic data. Unusual sightings are flagged for review and sent to one of nearly 1000 regional experts for individual review (CLO, 2018). Roughly $5 \%$ of all yearly submissions are flagged for review and nearly half of those are ultimately marked as invalid. The combination of artificial and human intelligence drastically increases the data quality before it becomes part of the eBird database (Kelling et al., 2015). Despite some issues, the quality of citizen science-sourced data has been shown to be generally reliable, particularly when coupled with online data filters and vetting such as that used by eBird (Cooper et al., 2014).

\section{METHODS}

\section{Study Site}

The state of Florida was selected with a particular focus on the ten southernmost counties comprising what is known as south Florida. South Florida has a tropical climate with a wet summer season and dry winter season. From 1963-2012 the mean minimum and maximum daily temperatures were respectively 18 and 29 degrees Celsius (National Climatic Data Center, Royal Palm Ranger Station; $\left.25^{\circ} 23^{\prime} \mathrm{N} / 80^{\circ} 36 \mathrm{~W}\right)$. The lowest daily temperatures occurred in January and the highest occurred in August. Most rainfall occurs between May and October and the mean annual precipitation was 138 centimeters (Davis 
\& Ogden, 1994). Despite containing vital habitats for migratory avian species, a lack of research on overwintering birds in south Florida represents a significant knowledge gap (Benscoter et al., 2013).

\section{Patterns in Overwintering Passerine Richness}

The eBird data were used as the source of all citizen science-sourced point-occurrence data. All vetted winter avian sightings in Florida between 2001 and 2017 were obtained from eBird online (https://ebird.org/home). Each sighting contained a species name, date observed, latitude and longitude. Observations were used to determine the total number of bird species and passerine species for the entire state of Florida. Winter sighting frequencies for each species were calculated by dividing the number of eBird submissions with that particular species present by the total number of submissions for that time period.

Understanding that species richness (i.e., the number of species detected) varies in space, a 50 by 50 grid ( $14 \mathrm{~km}^{2}$ resolution) was used to calculate the number of species detected within each grid cell using $R$ version 3.4.1 (R Core Team 2013) and the packages raster ( Hijmans 2016) and rgdal (Bivand et al., 2017). Richness layers (total bird richness and songbird richness) were developed to show linear trends in species richness with latitude and longitude using the R package rasterVis (Lamigueiro and Hijmans 2016).

\section{Choosing Target Species}

After compiling and analyzing $\mathrm{CBC}$ checklists from the past 30 years to corroborate the initial observed discrepancies between range maps and eBird histograms, fifteen passerine species were chosen for this study. These fifteen 
species - Cape May Warbler (Setophaga tigrina), Eastern Bluebird (Sialia sialis), Gray-cheeked Thrush (Catharus minimus), Hermit Thrush (Catharus guttatus), Hooded Warbler (Setophaga citrina), Indigo Bunting (Passerina cyanea), Louisiana Waterthrush (Parkesia motacilla), Magnolia Warbler (Setophaga magnolia), Orchard Oriole (Icterus spurius), Prothonotary Warbler (Protonotaria citrea), Summer Tanager (Piranga rubra), Swainson's Warbler (Limnothlypis swainsonii), Worm-eating Warbler (Helmitheros vermivorum), Yellow-breasted Chat (Icteria virens), and Yellow-throated Vireo (Vireo flavifrons)-were selected to evaluate discrepancies in expert-drawn range maps for overwintering passerines in south Florida.

\section{Evaluating Expert-drawn Range Map Discrepancies}

Expert-drawn range maps for all passerine species reported in south Florida in the winter were obtained from Audubon, Cornell, and NatureServe online. Each species range was examined on each range map and classified as either overwintering (winter only), migratory (spring and/or fall migration only), breeding (summer only), resident (year-round), or absent (south Florida not included in any part of its annual cycle). If all three range map classifications were not in agreeance, this was recorded as a discrepancy.

South Florida winter presences for all passerine species were then compared to the three aforementioned range map sources. Differences between the expert-drawn range maps and eBird sightings were used to reassess the south Florida winter occupancy for each target species and to test the null hypothesis stating that the range maps for these 15 species are consistent with 
eBird data. Because opportunistic citizen science-based occurrence data are inherently biased toward populated areas and birding hotspots, this study will not attempt to create new winter range maps based solely upon eBird sightings. Rather, point occurrence data will be used to help resolve range map discrepancies and provide enough evidence to pinpoint which expert-drawn range maps should be reevaluated.

\section{RESULTS}

\section{Patterns in Overwintering Songbird Richness}

A total of 717 species of birds were sighted during winter in Florida (20012017). Richness ranged from 1 to 311 different species per mapped cell for the entire state. The distribution of these sighting frequencies was relatively normal, with a higher-than-expected number of areas with low species sightings $(<5$ species) because of a lack of observations in certain regions (Figure 1). The highest rates of species richness occurred along both coasts and in larger city

centers (Figure 1). Temporally, the total number of species reported increased as years advanced (Figure 2). Of the 717 species observed throughout the state, 195 were passerines. South Florida contained the majority of species observed in the entire state (590), 168 of which were passerines. Few species were seen at frequencies greater than .01 (28 high-frequency species) while 59 were sighted at frequencies lower than .0001 (low-frequency species).

Species only reported in December and March were considered migrants as they went unreported in the winter months of January and February. In the 
state of Florida, the highest species richness of these migrants was found in the panhandle and northern part of the state (Figure 3). Within south Florida, the highest migrant species richness was found in the Florida Keys (Figure 4). In south Florida, 26 species were migratory only; 25 of these were low-frequency species. The remaining 142 species were seen throughout the winter months.

\section{Expert-drawn Range Map Discrepancies}

Of the 168 overwintering passerine species seen in south Florida, 28 were listed by all three expert-drawn range map sources as overwinterers. Another 28 species were described by all three range maps as living in south Florida yearround. NatureServe, Audubon, and Cornell did not agree upon the overwintering ranges of 40 sighted species (disputed species). Disputed species occurred across the full range of sighting frequencies; two were high-frequency and two were low-frequency with the remaining species falling in between these extremes.

Of the species whose ranges were agreed upon by all three range map sources, five were described as only being present in south Florida during the summer (despite being regularly seen during the winter months). Many passerine species 24\% (40 species), did not have south Florida listed as part of their overwintering ranges on all three expert-drawn range maps. Of these, 13 were western species and 17 were tropical or Caribbean species. The remaining ten species in this group were target species in this study.

One target species, Gray-cheeked Thrush (Catharus minimus), was not present within the vetted eBird sightings. The Gray-cheeked Thrush had two 
unconfirmed sightings between 2001 and 2017 that were eliminated by vetting protocols. This species was reported only once in the Christmas Bird Count between 2001 and 2015. As a result of its absence in this data-set, this species was not considered as a potential overwinterer for the purposes of this study.

The 14 remaining target species fell into the middle of the south Florida passerine species sightings rank-ratio (SSRR) curve, with none of them among either the most or least-sighted species (Figure 5). While some years did not contain sightings of six of these species, all species were reported in at least eight out of the most recent ten years. Eight of the 14 target species were sighted every year during the study period (Figure 6). The Worm-eating Warbler (Helmitheros vermivorum), Yellow-breasted Chat (Icteria virens), Orchard Oriole (Icterus spurius), Swainson's Warbler (Limnothlypis swainsonii), Louisiana Waterthrush (Parkesia motacilla), Prothonotary Warbler (Protonotaria citrea), Hooded Warbler (Setophaga citrina), and Magnolia Warbler (Setophaga magnolia) were classified as only migrating through south Florida by all three expert-drawn range maps. The most commonly-seen target species, the Indigo Bunting (Passerina cyanea), was listed by Audubon and Cornell as overwintering in south Florida while NatureServe describes this species as only breeding in the region (Table 1).

The Summer Tanager (Piranga rubra) was the only target species with an expert-drawn range map completely excluding south Florida from its range (Cornell) while the other two listed it as migratory only. Both the Hermit Thrush (Catharus guttatus) and the Yellow-throated Vireo (Vireo flavifrons) were listed by 
some range maps as only being south Florida migrants while others listed them as overwinterers. The Indigo Bunting (Passerina cyanea) was the only target species listed as only breeding in south Florida by an expert-drawn range map (NatureServe), although both Cornell and Audubon list it as an overwinterer. The Eastern Bluebird (Sialia sialis) was the only species to be listed differently by each range map source, with NatureServe reporting it as a migrant, Audubon as a year-round resident, and Cornell as an overwinterer (Table 1).

Although, all three range maps list the Cape May Warbler (Setophaga tigrina) as overwintering in south Florida, both NatureServe and Cornell report this species as only overwintering in the Florida Keys. Audubon lists it as overwintering throughout the state. While winter eBird sightings of the Cape May warbler were reported throughout the Keys, most sightings occurred on the east coast of south Florida in Miami-Dade and Broward counties (Figure 7). In summary, these fourteen species all appear to be overwintering in south Florida and analyses suggest that the status of these species warrants further examination of current expert-drawn range maps.

\section{DISCUSSION}

\section{Florida Species Richness}

Florida has some of the highest avian species richness in the continental United States (USGS, 2015). Although the results from my study support this fact, the total number of species reported in Florida on eBird is higher than reported elsewhere. The Florida Ornithological Society (FOS) lists a total of 683 
avian species in the entire state throughout the year using both historical records and surveys, substantially fewer than the 717 species reported on eBird between 2001 and 2017 in winters alone (FOS, 2017). While the eBird total could be inflated because of misidentification, it is also possible that the FOS committee which vets observational data disregards a high volume of what it deems to be unusual or erroneous sightings.

However, what is considered an unusual sighting in Florida might be changing; the winter ranges of North America's migratory species are already shifting. While most winter species are predicted to shift as much as $100 \mathrm{~km}$ north by 2080 , over one quarter of non-breeding avian taxa are predicted to shift south (Langham et al, 2015). The disparity between these sighting numbers coupled with current range-shifting trends suggests a closer examination of both eBird and FOS data vetting is required. However, while eBird vetting methods are publicly available, those of the FOS are not.

Wetlands and coastal habitats constitute a greater percentage of Florida's land surface than any other state in the conterminous United States (UGSG, 2015). Given that many of the non-passerine species in the state are shorebirds and waterfowl, it is unsurprising that the greatest overall avian species richness in the state was found along the east and west coasts. The high species richness in city centers is likely an effect of more populated areas yielding a greater number of eBird observations, a pattern reflected in sightings increasing temporally as more birders take advantage of using smart phones and personal computers to report eBird sightings. 
High urban levels of species richness could also reflect a general trend of species richness in urban areas increasing as latitudes decrease. Suburban areas populated by residences, yards, gardens and parks can also be speciesrich, with migratory birds intermingling with residential species in vegetative patches (Jokimaki \& Kaisanlhat-Jokimaki, 2012). The presence of year-round flowering plants in south Florida's suburban neighborhoods likely bolsters its ability to support many different species in the winter.

\section{South Florida Species Richness}

Of the entire state's winter birds, $82 \%$ were sighted in south Florida. The proportion of passerines to total birds was nearly identical when comparing south Florida to the rest of the state; $27 \%$ of the state's reported birds were passerines compared to south Florida's $28 \%$. While my study did not attempt to examine birds migrating through the state without overwintering within it, identifying species only reported in the first and last months of the winter season did serve to distinguish species that were either late fall or early spring migrants. The highest species richness of these migrants was found in the northernmost and southernmost portions of the state. The Mississippi and Atlantic flyways converge over northern Florida, likely exposing this region to a great diversity of migrating birds (FFWC, 2014).

In south Florida, however, the highest species richness of migrant passerines was found in the Florida Keys. Here, birds that have migrated through the state peninsula can intermingle with those flying to overwintering grounds in the Caribbean and Neotropics via the Gulf of Mexico (BirdLife International, 
2016). While the peninsula effect has been observed in breeding bird populations, it has not been applied to migratory or overwintering bird populations (Jo et al., 2017). The species richness trends observed in Florida strongly suggest that migratory flyways and dynamics have stronger impacts on the state's avian populations than do peninsular effects.

\section{Expert-drawn Range Map Discrepancies}

Range map discrepancies were present for a staggering $66 \%$ of all reported winter passerines in south Florida. The underlying uncertainty about the winter ranges of a majority of the passerine species seen in south Florida has potentially enormous consequences. Expert-drawn range maps are used as the basis of broad-scale avian distributional studies and inform conservation planning and public policy (La Sorte \& Hawkins, 2007). For example, NatureServe range maps are used by the United States Forest Service to identify species of conservation concern when creating land management policies. These maps are also used by the U.S. Environmental Protection Agency, the Pipeline and Hazardous Materials Safety Administration, the Western Electricity Coordinating Council, and the Sustainable Forestry Initiative. Additionally, NatureServe range maps have been cited over 5,000 times in peer-reviewed journals (NatureServe, 2016).

Discrepancies among these three range map sources for so many birds hints at a potentially devastating crisis. If public policy impacting migratory passerines is being drawn using outdated avian ranges, already-vulnerable species could be further threatened. As conditions in avian overwintering 
grounds have an enormous effect on populations' fitness and survivorship, accurately identifying winter ranges is a crucial part of effectively protecting migratory birds (Mehlman et al., 2005).

Of the three map sources used in this study, only NatureServe makes their map-creating protocols publicly available. However, the methodology outlined on their website is no longer current. While the site states that individual state agencies annually supply NatureServe with data to update their range maps, the last update from Florida occurred in 2003. I contacted The Florida Natural Areas Inventory (FNAI), the Florida agency charged with sending local data to NatureServe. The director explained that the only avian data they now send to NatureServe is for 74 species of concern, of which only 26 are passerines. With regard to most of Florida's bird species, NatureServe's maps are therefore based upon old, potentially obsolete data.

I also repeatedly contacted the National Audubon Society and Cornell Lab of Ornithology in an attempt to uncover how these organizations create their range maps. A representative from Cornell explained that updates of their range maps, while incorporating citizen science observations, are often reliant upon a single expert or small team making judgement calls based upon the best available data. This methodology is also used by most published field guides. Cornell never responded to follow-up inquiries about specific analytical protocols, vetting standards, or a timetable for range map updates. Requests to the Audubon Society for their range map protocols went unanswered. With limited 
transparency and no single set of protocols used for creating expert-drawn range maps, widespread discrepancies should therefore be unsurprising.

\section{$\underline{\text { Target Species }}$}

Fourteen target species had range discrepancies, with a majority of them reported by all three range map sources as only being present in south Florida during spring and fall migration. However, when sightings from the months of December and March were removed from this data set, all target species were still regularly sighted in south Florida throughout the winter over the seventeenyear period of the eBird data set. The observations provide strong indication that these birds remain in south Florida outside of these migratory periods. Three species were primarily seen in localized regions within south Florida. The Cape May Warbler (Setophaga tigrina) was seen almost exclusively in the Florida Keys and along the southeastern coast (Figure 7l). The Yellow-breasted Chat (Icteria virens) was seen primarily along Florida's east coast (Figure 7c). Eastern Bluebird (Sialis sialis) sightings were on the west coast and in the northernmost extent of south Florida (Figure $7 \mathrm{~m}$ ). The eleven remaining species were consistently seen throughout south Florida.

The evidence therefore strongly suggests that all of these target species overwinter in south Florida. Although the target species were not among the highest-frequency birds in this data set, none of the target species ranked with the least-commonly seen winter passerines in south Florida. The target species fell into the middle of the SSRR curve, occupying the most-commonly sighted half of the species within its tail. This pattern of distribution featuring a small 
number of abundant species coupled with a long tail of low abundance species is a common phenomenon amongst disparate locales and taxa. The populous species are most often uncommon throughout their range while only appearing abundant in certain locations or times. Certain habitats and sites can, however, continually favor high numbers of these "somewhere-abundant" species. Studies suggest that these sites are likely to be found near the center of a species' geographic range, further bolstering the need for accurate range maps (Murray et al.,1999).

\section{Non-target Species}

Even commonly-observed, non-target species had disputed ranges. The Pine Warbler (Setophaga pinus) had one of the highest sighting ratios of all south Florida's winter warblers and was ranked $21^{\text {st }}$ among all winter passerine sighting ratios. Audubon lists the species as a south Florida overwinterer. However, NatureServe did not include south Florida in the winter range although it was classified as a year-round resident throughout the central and northern regions of the state. Cornell also considers this species a resident throughout most of Florida but depicts it as absent in south Florida aside from a small area west of Lake Okeechobee.

All three range map sources agree that another high-frequency species, the Prairie Warbler (Setophaga discolor) is present in much of south Florida during the winter. However, NatureServe lists the Prairie Warbler as a year-round resident throughout the state while Cornell and Audubon only consider parts of coastal south Florida's populations residential. These range maps depict the 
central part of south Florida as home to overwintering Prairie Warblers only. Disparities among high-frequency species illustrate how widespread range map discrepancies are with regards to south Florida's winter birds.

The difficulty of distinguishing between migratory and residential populations of the same species is also reflected in these discrepancies. Widespread differences between current eBird sightings and existing range maps suggests generating new expert-drawn range maps using a combination of different, independently-sourced data collection techniques such as markrecapture, point counts, and opportunistic surveys. Creating range maps this way could help keep them current while creating a more accurate picture of local species diversity (Hawkins et al., 2008). My study suggests that our knowledge of how and when migratory birds occupy south Florida is greatly lacking. Without accurate and current expert-drawn range maps, effectively managing and conserving these species will impossible.

\section{FUTURE RESEARCH AND CONCLUSION}

Although Florida is predicted to have less overall warming than most other North American regions, it is already experiencing greater climatic extremes than the rest of the lower 48 states (Benscoter et al., 2013). In Florida, the past century has seen significant increases in maximum, minimum, and mean temperatures during most months (Martinez et al., 2012). While temperature is a major driver of changes in migratory behavior and avian fitness, precipitation can also affect birds by regulating food supplies. Variations in water availability can 
ultimately contribute to limiting and regulating avian populations with decreased rainfall on overwintering habitats resulting in overall body mass declines and increased mortality over the entire season (Benscoter et al., 2013).

Yearly rainfall levels in the Caribbean are predicted to decline significantly over the next five decades with a profound effect on habitat quality and the fitness of wildlife within its vegetative communities. The severity of tropical storms and hurricanes is also predicted to increase. If Caribbean habitats become unsuitable overwintering habitats for migratory birds, many species are likely to experience population declines and shifts in winter ranges (Mith et al., 2010). Florida's local fauna is already threatened by high human population growth rates, invasive species, and climate change. The state is also vulnerable to changing coastlines with expected increases in sea levels predicted to submerge or drastically alter the Florida Keys, coastal areas, barrier islands, and large swathes of the Everglades (von Holle et al., 2010).

Migratory birds are particularly prone to population declines stemming from global climate change, a major driver of biodiversity reduction (Jiguet et al., 2007). Indeed, over half of all migratory bird species have experienced population declines over the past three decades (Runge et al., 2015). With shifts in phenology representing one of the most widely-cited pieces of evidence that species are responding to climate change, studying when and how long birds occupy seasonal habitats should be considered a necessary part of assessing the overall impact of climate change on animal species in general (Cooper et al., 2014). 
Despite recent research indicating that many overwintering bird populations are shifting, no study has examined changes in subtropical North American overwintering territories. South Florida occupies the northernmost edge of many species' winter ranges and represents a unique confluence of temperate and tropical habitats. Analyzing range shifts for this region's overlooked birds would therefore fill an important knowledge gap. This study not only rejects the null hypothesis that the expert-drawn range maps for my 15 target species are consistent with eBird data, but also exposes a potential crisis in our ability to accurately assess and manage avian populations. With its tropical habitats particularly vulnerable to climate change, south Florida's effective management of migratory birds depends upon generating more accurate range maps.

The discrepancies revealed by this study also indicate large-scale issues with expert-drawn range maps in general. As the baseline for many public policy and management decisions, range maps must be scrutinized to ensure that they reflect the current ranges of migratory birds. Incorporating current citizen science data can harness the observational power of tens of thousands of birdwatchers to increase the accuracy of range maps. Until these maps are standardized, made public, and incorporate the most current available data, countless studies and policies could be based upon erroneous assumptions about avian species ranges. 


\section{REFERENCES}

Adams, Lowell W. (1994). Urban wildlife habitats: a landscape perspective. Minneapolis: University of Minnesota Press.

Amano, T., Lamming, J. D. L., Sutherland, W. J., Benscoter, A. M., Reece, J. S., Noss, R. F., Kelling, S. (2015). Spatiotemporal variation in avian migration phenology: Citizen science reveals effects of climate change. PLOS ONE, 6(2), 1-14. http://doi.org/10.1111/ibi.12227

Amano, T., Lamming, J. D. L., \& Sutherland, W. J. (2016). Spatial gaps in global biodiversity information and the role of citizen science. BioScience, 66(5), 393-400. http://doi.org/10.1093/biosci/biw022

Audubon Guide to North American Birds (2018). http://www.audubon.org.

Barbosa, A., Estrada, A., Márquez, A. L., Purvis, A., \& Orme, C. D. L. (2012). Atlas versus range maps: robustness of chorological relationships to distribution data types in European mammals. Journal of Biogeography, 39(8), 1391-1400. http://doi.org/10.1111/j.1365-2699.2012.02762.x

Benscoter, A. M., Reece, J. S., Noss, R. F., Brandt, L. A., Mazzotti, F. J., Romañach, S. S., \& Watling, J. I. (2013). Threatened and endangered subspecies with vulnerable ecological traits also have high susceptibility to sea level rise and habitat fragmentation. PLOS ONE, 8(8), 1-11. http://doi.org/10.1371/journal.pone.0070647

BirdLife International (2016). http://www.birdlife.org.

Bivand, R.,Keitt, T. \& Rowlingson, B., (2017). rgdal: Bindings for the 'geospatial' data abstraction library. R package version 1.2-16. https://CRAN.Rproject.org/package=rgdal

Cantú-Salazar, L., \& Gaston, K. J. (2013). Species richness and representation in protected areas of the western hemisphere: Discrepancies between checklists and range maps. Diversity and Distributions, 19(7), 782-793. http://doi.org/10.1111/ddi.12034

Chace, J. F., \& Walsh, J. J. (2006). Urban effects on native avifauna: a review. Landscape and Urban Planning, 74(1), 46-69. http://doi.org/10.1016/j.landurbplan.2004.08.007

Cooper, C. B., Shirk, J., \& Zuckerberg, B. (2014). The invisible prevalence of citizen science in global research: migratory birds and climate change. PLOS ONE, 9(9), 1-6. http://doi.org/10.1371/journal.pone.0106508 
CLO, Cornell Lab of Ornithology (2018). http://www.birds.cornell.edu.

Davis, S. M., and Ogden, J.C. Eds. (1994), Everglades: the ecosystem and Its restoration, St. Lucie Press, Boca Raton, Fla.

Faaborg, J., Holmes, R. T., Anders, a. D., Bildstein, K. L., Dugger, K. M., Gauthreaux, S. A., ... Others. (2010). Conserving migratory landbirds in the New World: Do we know enough? Ecological Applications, 20(2), 398-418. http://doi.org/10.1890/09-0397.1

Farnsworth, A., Sorte, F. A. L. A., \& lliff, M. J. (2015). Warmer summers and drier winters correlate with more winter vagrant Purple Gallinules ( Porphyrio Martinicus) in the North Atlantic region. The Wilson Journal of Ornithology, 127(4), 582-592.

Florida Birding Trail. (2012). http://floridabirdingtrail.com/wpcontent/uploads/2016/03/16chklist_fillable.pdf

FFWC, Florida Fish \& Wildlife Conservation Commission. (2014). http://myfwc.com/research/wildlife/birds/

FOS, Florida Ornithological Society (2017). http://www.fosbirds.org.

Gordon, D. R. (1998). Effects of invasive, non-indigenous plant species on ecosystem processes: lessons from Florida. Ecological Applications, 8(4), 975-989. http://doi.org/10.2307/2640955

Habib, L. D., Wiersma, Y. F., \& Nudds, T. D. (2003). Effects of errors in range maps on estimates of historical species richness of mammals in Canadian national parks. Journal of Biogeography, 30(3), 375-380.

Hawkins, B. A., Porter, E. E., \& Diniz-Filho, J. A. F. (2014). Productivity and history as predictors of the latitudinal diversity gradient of terrestrial birds. Ecology, 84(6), 1608-1623.

Hawkins, B. A., Rueda, M., \& Rodríguez, M. Á. (2008). What do range maps and surveys tell us about diversity patterns? Folia Geobotanica, 43(3), 345-355. http://doi.org/10.1007/s12224-008-9007-8

Hayes, F. E. (1995). Definitions for migrant birds: what is a Neotropical migrant? The Auk, 112(2), 521-523.

Hedenstrom, A. (2008). Adaptations to migration in birds: behavioural strategies, morphology and scaling effects. Philosophical Transactions of the Royal Society B, 363, 287-299. http://doi.org/10.1098/rstb.2007.2140 
Hijmans, Robert J. (2016). raster: Geographic data analysis and modeling. R package version 2.5-8. https://CRAN.R-project.org/package=raster

Hurlbert, A. H., \& Haskell, J. P. (2003). The effect of energy and seasonality on avian species richness and community composition. American Naturalist, 161(1), 83-97. http://doi.org/10.1086/345459

Jetz, W., \& Rahbek, C. (2002). Geographic range size and determinants of avian species richness. Science, 297(5586), 1548-1551.

http://doi.org/10.1126/science.1072779

Jiguet, F., Gadot, A.-S., Julliard, R., Newson, S. E., \& Couvet, D. (2007). Climate envelope, life history traits and the resilience of birds facing global change. Global Change Biology, 13, 1672-1684. http://doi.org/10.1111/j.13652486.2007.01386.

Jo, Y. S., Stevens, R. D., \& Baccus, J.T. (2017). Peninsula effect and species richness gradient in terrestrial mammals on the Korean Peninsula and other peninsulas. Mammal Review, 47(4), 266-276. http://doi.org/10.1111/mam.12094.

Jokimäki, J., \& Kaisanlahit-Jokimäki, M.L. (2012). Residential areas support overwintering possibilities of most bird species. Annales Zoologici Fennici, 49(August), 240-256.

Keast, A., \& Morton, E.S. (1980). Migrant birds in the Neotropics: Ecology, behavior, distribution, and conservation: a symposium held at the Conservation and Research Center, National Zoological Park, Smithsonian Institution, October 27-29, 1977. Washington, D.C: Smithsonian Institution Press.

Kelling, S., Fink, D., Sorte, F. A. La, Johnston, A., Bruns, N. E., \& Hochachka, W. M. (2015). Taking a "Big Data" approach to data quality in a citizen science project. Ambio, 44(4), 601-611. http://doi.org/10.1007/s13280-015-0710-4

La Sorte, F. A., Fink, D., Blancher, P. J., Rodewald, A. D., Kenneth, V. R., Wesley, V. R., Kelling, S. (2017). Global change and the distributional dynamics of migratory bird populations wintering in Central America. Global Change Biology, 0, 1-13. http://doi.org/10.1111/gcb.13794

La Sorte, F. A., Fink, D., Hochachka, W. M., Farnsworth, A., Rodewald, A. D., Rosenberg, K. V., Kelling, S. (2014). The role of atmospheric conditions in the seasonal dynamics of North American migration flyways. Journal of Biogeography, 41(9), 1685-1696. http://doi.org/10.1111/jbi.12328 
La Sorte, F. A., \& Hawkins, B. A. (2007). Range maps and species richness patterns: Errors of commission and estimates of uncertainty. Ecography, 30(5), 649-662. http://doi.org/10.1111/j.2007.0906-7590.05084.x

Lamigueiro, O.P., and Hijmans, R., (2016), meteoForecast. R package version 0.41 .

Langham, G. M., Schuetz, J. G., Distler, T., Soykan, C. U., \& Wilsey, C. (2015). Conservation status of North American birds in the face of future climate change. PLOS ONE, 1-16. http://doi.org/10.1371/journal.pone.0135350

Latta, S. C., \& Faaborg, J. (2009). Benefits of studies of overwintering birds for understanding resident bird ecology and promoting development of conservation capacity. Conservation Biology, 23(2), 286-293. http://doi.org/10.1111/j.1523-1739.2008.01098.x

Márcia Barbosa, A., Estrada, A., Márquez, A. L., Purvis, A., \& Orme, C. D. L. (2012). Atlas versus range maps: Robustness of chorological relationships to distribution data types in European mammals. Journal of Biogeography, 39(8), 1391-1400. http://doi.org/10.1111/j.1365-2699.2012.02762.x

Martinez, C. ., Maleski, J. ., \& Miller, M. . (2012). Trends in precipitation and temperature in Florida, USA. Journal of Hydrology, 452-453, 259-281.

Marzluff J.M., Ewing, K .,(2001). Restoration of fragmented landscapes for the conservation of birds: a general framework and specific recommendations for urbanizing landscapes. Restoration Ecology, 9, 280-292.

McKinney, M. L. (2008). Effects of urbanization on species richness: A review of plants and animals. Urban Ecosystems, 11(2), 161-176. http://doi.org/10.1007/s11252-007-0045-4

Mehlman, D. W., Mabey, S. E., Ewert, D. N., Duncan, C., Abel, B., Sutter, R. D., \& Woodrey, M. (2005). Conserving stopover sites for forest-dwelling migratory landbirds. The Auk, 122(4), 1281-1290.

Merow, C., Wilson, A. M., \& Jetz, W. (2017). Integrating occurrence data and expert maps for improved species range predictions. Global Ecology and Biogeography, 26, 243-258.

Mith, J. O. A. M. S., Eitsma, L. E. R. R., \& Marra, P. P. (2010). Moisture as a determinant of habitat quality for a nonbreeding Neotropical migratory songbird. Ecology, 91(10), 2874-2882. 
Murray, B. R., Rice, B. L., Keith, D. A., Myerscough, J., Howell, J., Floyd, A. G.,Mills, K., Westoby, M. (1999). Species in the tail of rank - abundance curves. Ecology, 80(6), 1806-1816. http://doi.org/10.1890/00129658(1999)080[1806:sittor]2.0.co;2

NatureServe (2016). http://www.natureserve.org.

Peck, S. (1989). A Survey of Insects of the Florida Keys: post-Pleistocene landbridge islands introduction. The Florida Entomologist, 72(4), 603-612. doi:10.2307/3495034

Princé, K., \& Zuckerberg, B. (2015). Climate change in our backyards: the reshuffling of North America's winter bird communities. Global Change Biology, 21(2), 572-585. http://doi.org/10.1111/gcb.12740

R Core Team (2013). R: A language and environment for statistical computing. $R$ Foundation for Statistical Computing, Vienna, Austria. URL http://www.Rproject.org/.

Rahbek, C., \& Graves, G. R. (2001). Multiscale assessment of patterns of avian species richness. Proceedings of the National Academy of Sciences, 98(8), 4534-4539. http://doi.org/10.1073/pnas.071034898

Rodgers, L. R., Pernas, T., Redwine, J., Shamblin, B., \& Bruscia, S. (2018). Multiscale invasive plant monitoring: experiences from the Greater Everglades Restoration Area. Weed Technology, 32(1), 11-19. http://doi.org/10.1017/wet.2017.106

Runge, C., Watson, J. E. M., Butchart, S. H. M., Hanson, J. O., Possingham, H. P., \& Fuller, R. A. (2015). Protected areas and global conservation of migratory birds. Science, 350(6265), 1255-1258.

Sibley, David, Chris Elphick, John B. Dunning Jr. (2013). "Behavior." The Sibley Guide to Bird Life \& Behavior. 53-65.

Somershoe, S. G., Brown, C. D., \& Poole, R. T. (2009). Winter site fidelity and overwinter site persistence of passerines in Florida. The Wilson Journal of Ornithology, 121(1), 119-125. http://doi.org/10.1676/07-142.1

Sullivan, B. L., Wood, C. L., lliff, M. J., Bonney, R. E., Fink, D., \& Kelling, S. (2009). eBird: A citizen-based bird observation network in the biological sciences. Biological Conservation, 142(10), 2282-2292. http://doi.org/10.1016/j.biocon.2009.05.006 
Thomas, L., \& Martin, K. (1996). The importance of analysis method for breeding bird survey population trend estimates. Conservation Biology, 10(2), 479490.

Tubelis, D. P., Lindenmayer, D. B., \& Cowling, A. (2007). The peninsula effect on bird species in native eucalypt forests in a wood production landscape in Australia. Journal of Zoology, 271(1), 11-18. http://doi.org/10.1111/j.1469_ 7998.2006.00174.

USFWS, U.S. Fish \& Wildlife Service: Neotropical Migratory Bird Conservation Act. https://www.fws.gov/birdhabitat/grants/nmbca/birdlist.shtm

USGS, U.S. Geological Survey (2015). http://www.usgs.gov.

van Strien, A., Pannekoek, J., Hagemeijer, W., \& Verstrael, T. (2004). A loglinear Poisson regression method to analyse bird monitoring data. In Bird Census News: Proceedings of the International Conference and 13th Meeting of the European Bird Census Council (Vol. 13, pp. 33-39).

von Holle, B., Wei, Y., \& Nickerson, D. (2010). Climatic variability leads to later seasonal flowering of Floridian plants. PLOS ONE, 5(7), 1-10. http://doi.org/10.1371/journal.pone.0011500

Walker, J., \& Taylor, P. D. (2017). Using eBird data to model population change of migratory bird species. Avian Conservation and Ecology, 12(1), 1-24.

Wiggins, D. A. (2013). The Peninsula Effect on Species Diversity: A reassessment of the avifauna of Baja California. Ecography, 22(5), 542-547. 


\section{TABLES}

\begin{tabular}{|c|c|c|c|c|c|}
\hline Species & Overall sighting ranking & Average Sightings Ratio & NatureServe Range Map Status & Audubon Range Map Status & Cornell Range Map Status \\
\hline $\begin{array}{l}\text { Cape May Warbler } \\
\text { (Setophaga tigrina) }\end{array}$ & 76 & 0.000483 & Overwinterer (Keys Only) & Overwinterer & Overwinterer (Keys Only) \\
\hline $\begin{array}{l}\text { Eastern Bluebird } \\
\text { (Sialia sialis) }\end{array}$ & 44 & 0.003332 & Migrant & Resident & Overwinterer \\
\hline $\begin{array}{c}\text { Hermit Thrush } \\
\text { (Catharus guttatus) }\end{array}$ & 68 & 0.000588 & Migrant & Overwinterer & Migrant \\
\hline $\begin{array}{c}\text { Hooded Warbler } \\
\text { (Setophaga citrina) }\end{array}$ & 79 & 0.000444 & Migrant & Migrant & Migrant \\
\hline $\begin{array}{c}\text { Indigo Bunting } \\
\text { (Passerina cyanea) }\end{array}$ & 41 & 0.003711 & Breeding & Overwinterer & Overwinterer \\
\hline $\begin{array}{l}\text { Louisiana Waterthrush } \\
\text { (Parkesia motacilla) }\end{array}$ & 72 & 0.000553 & Migrant & Migrant & Migrant \\
\hline $\begin{array}{c}\text { Magnolia Warbler } \\
\text { (Setophaga magnolia) }\end{array}$ & 61 & 0.001079 & Migrant & Migrant & Migrant \\
\hline $\begin{array}{l}\text { Orchard Oriole } \\
\text { (Icterus spurius) }\end{array}$ & 107 & 0.000111 & Migrant & Migrant & Migrant \\
\hline $\begin{array}{l}\text { Prothonotary Warbler } \\
\text { (Protonotaria citrea) }\end{array}$ & 87 & 0.000262 & Migrant & Migrant & Migrant \\
\hline $\begin{array}{l}\text { Summer Tanager } \\
\text { (Piranga rubra) }\end{array}$ & 62 & 0.001055 & Migrant & Migrant & Absent \\
\hline $\begin{array}{c}\text { Swainson's Warbler } \\
\text { (Limnothlypis swainsonii) }\end{array}$ & 106 & 0.000123 & Migrant & Migrant & Migrant \\
\hline $\begin{array}{c}\text { Worm-eating Warbler } \\
\text { (Helmitheros vermivorum) }\end{array}$ & 65 & 0.00079 & Migrant & Migrant & Migrant \\
\hline $\begin{array}{l}\text { Yellow-Breasted Chat } \\
\text { (Icteria virens) }\end{array}$ & 91 & 0.000224 & Migrant & Migrant & Migrant \\
\hline $\begin{array}{l}\text { Yellow-throated Vireo } \\
\text { Vireo flavifrons }\end{array}$ & 60 & 0.001208 & Migrant & Overwinterer & Overwinterer \\
\hline
\end{tabular}

Table 1: Target Species Sightings Ranks and Range Map Statuses. Ranks are from 1-168, from most- to least-sighted (2001-2017). 


\section{FIGURES}

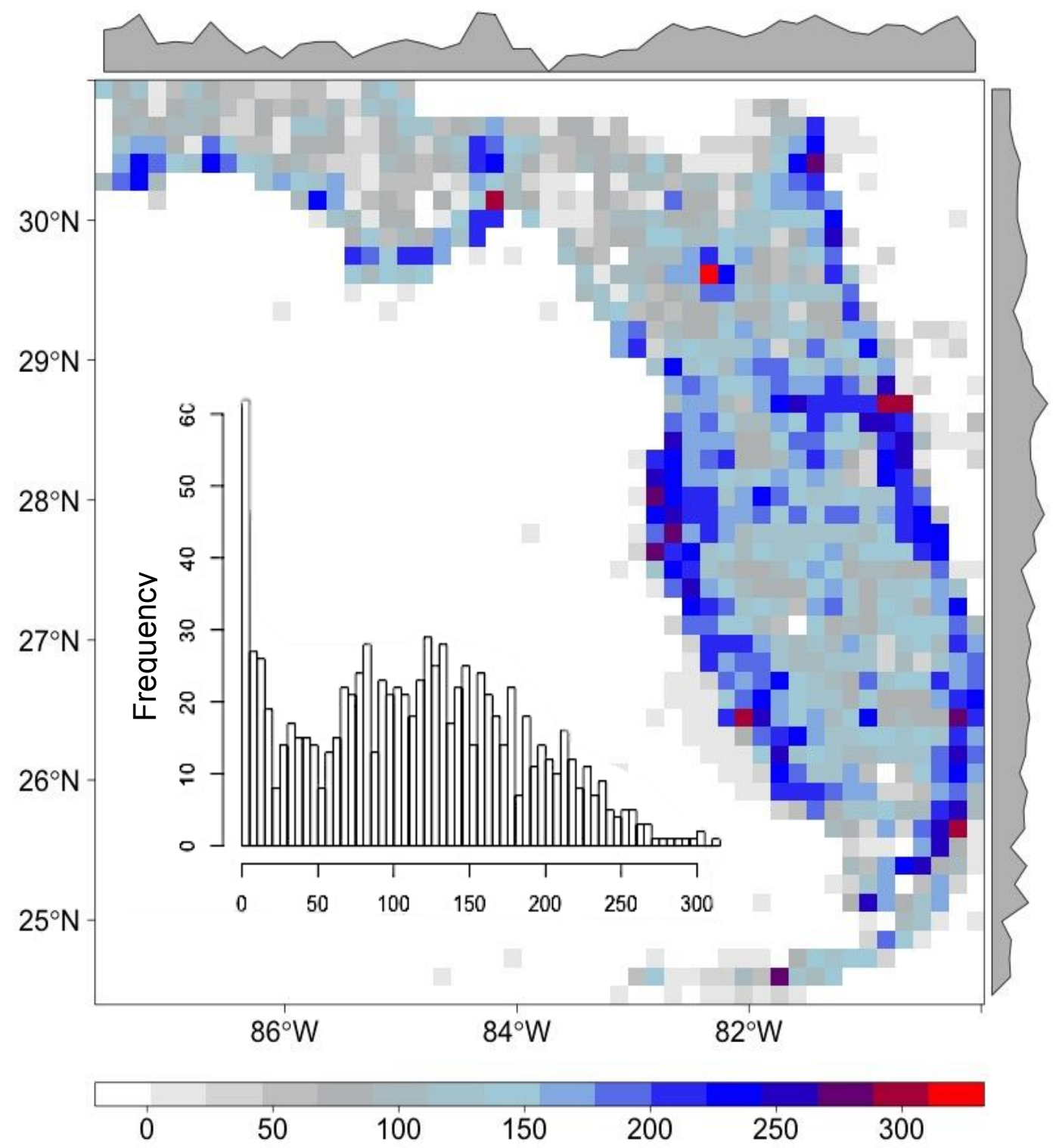

Figure 1: Florida's Winter Avian Species Richness and Frequency. Depicts the number and frequency of all species (0-300) throughout the state of Florida (2001-2017). 


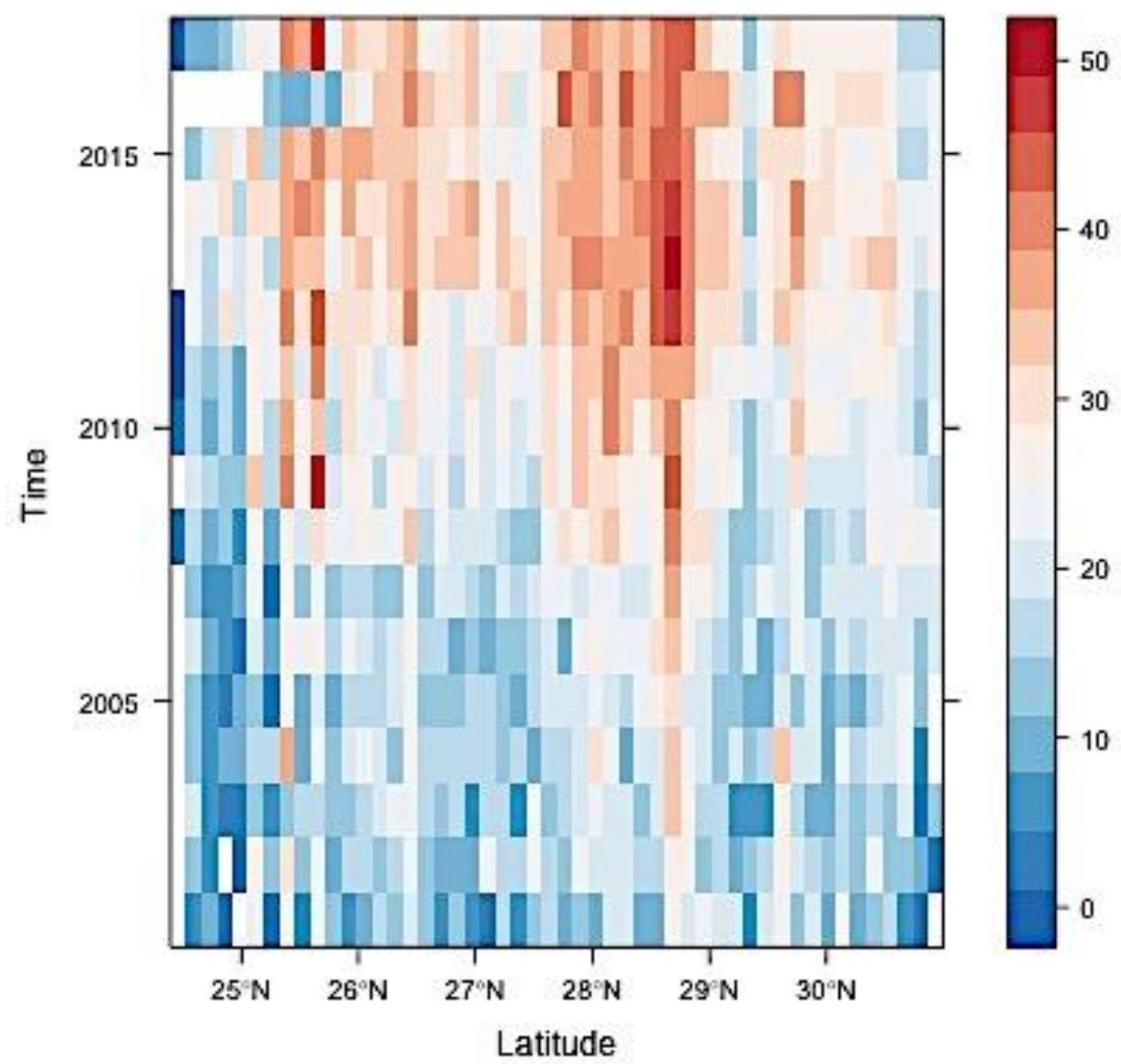

Figure 2: Temporal Changes in Species Richness. Depicts changes in detected species rcihness for all overwintering birds in the state of Florida (2001-2017). 


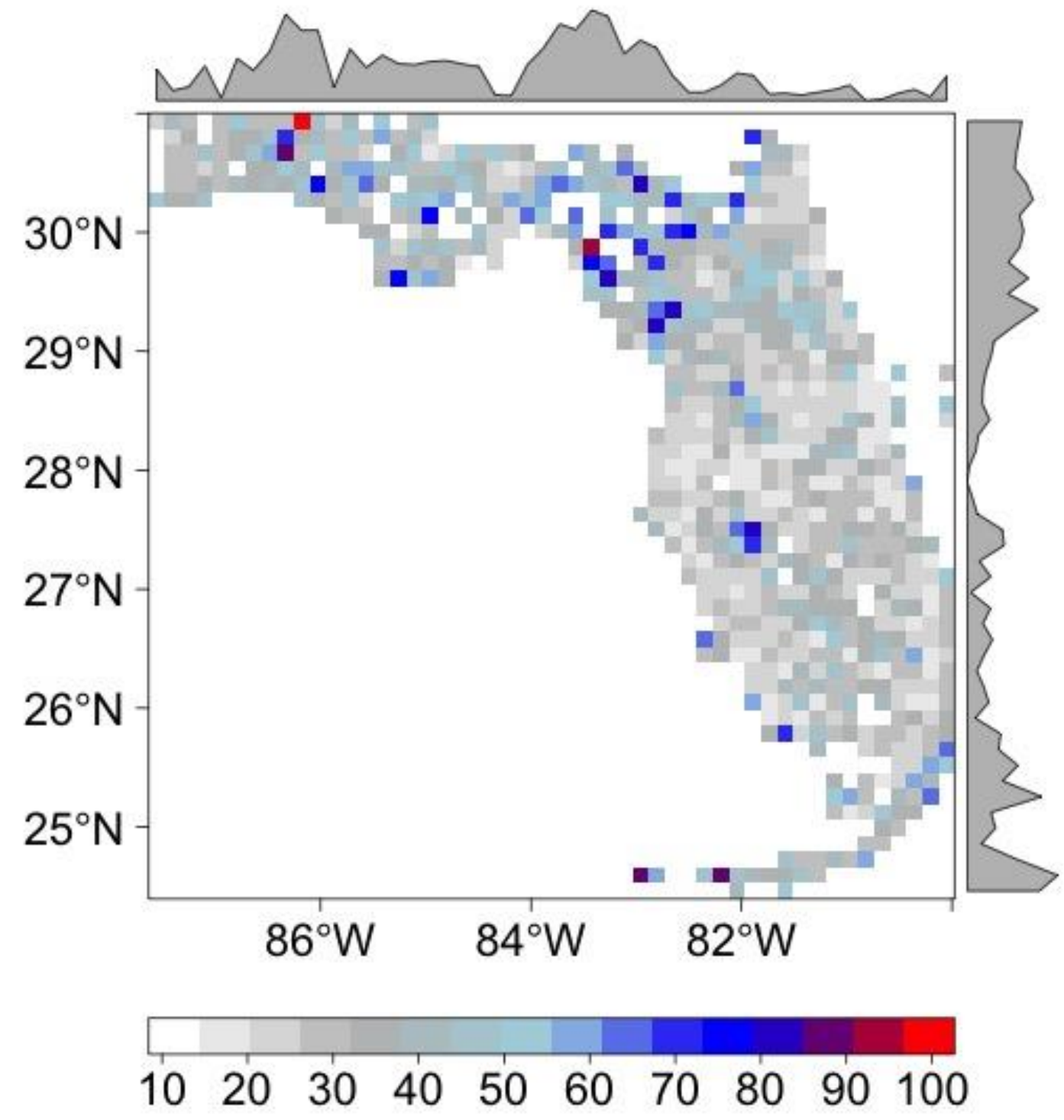

Figure 3: Florida's Migratory Winter Birds. Depicts the percentage of all winter birds in Florida only detected in December and March (2001-2017). 


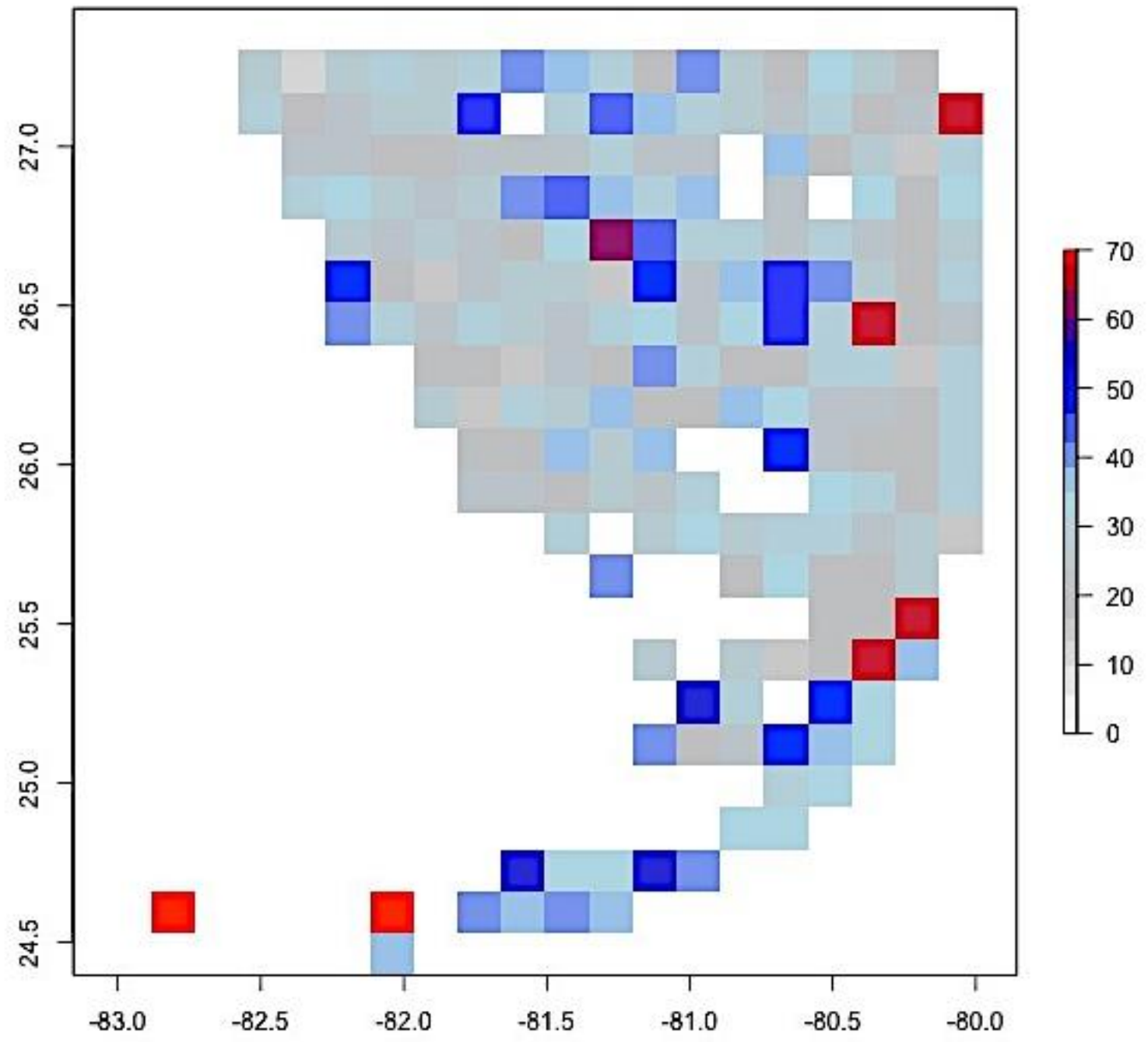

Figure 4: South Florida's Migratory Winter Passerines. Depicts the percentage of winter passerines only detected in December and March (2001-2017). 


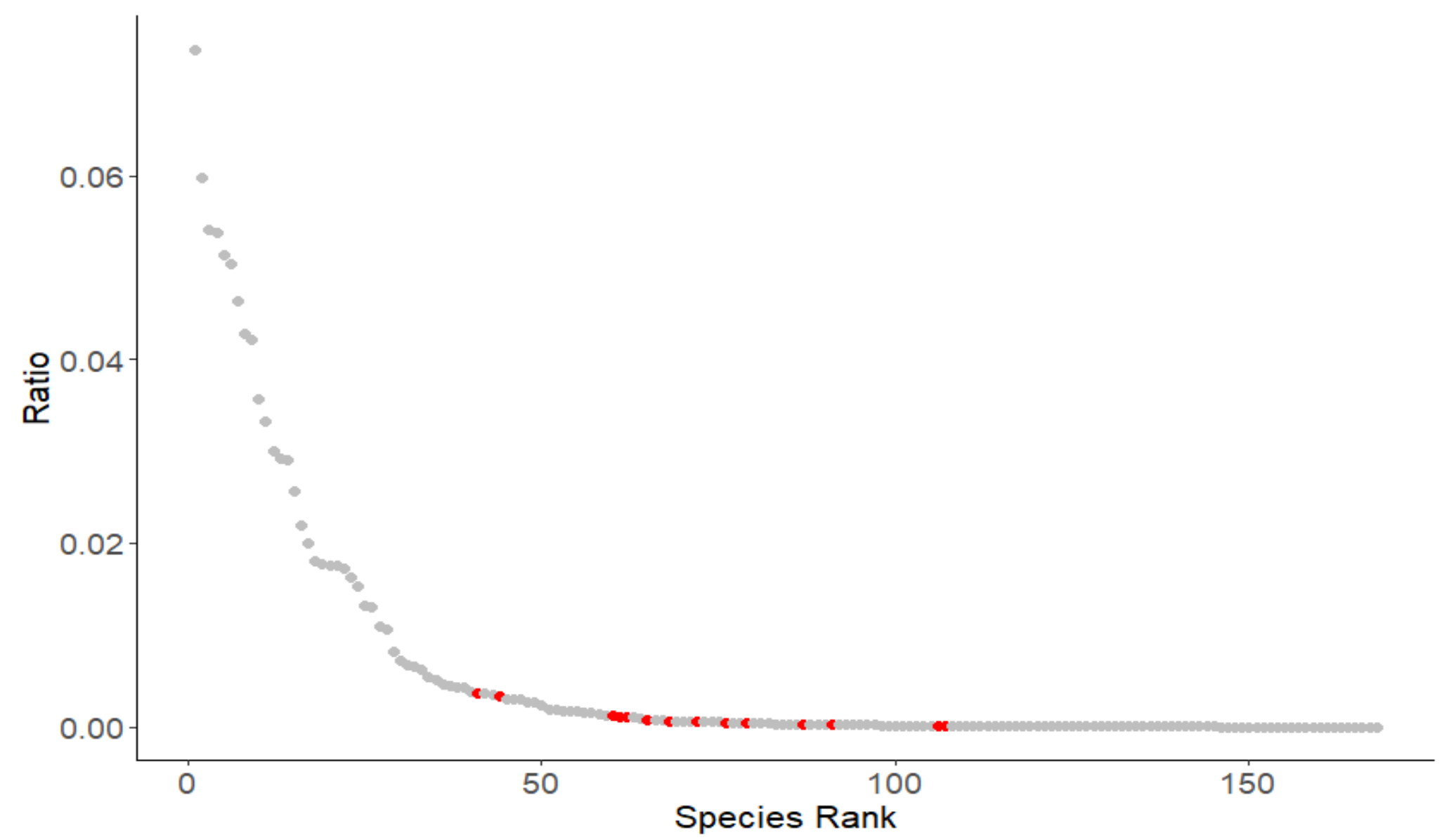

Figure 5: Species Sightings Rank-Ratio (SSRR) Curve. Depicts the distribution of south Florida's winter passerines based on frequency of sightings (2001-2017). Target species pictured in red. 


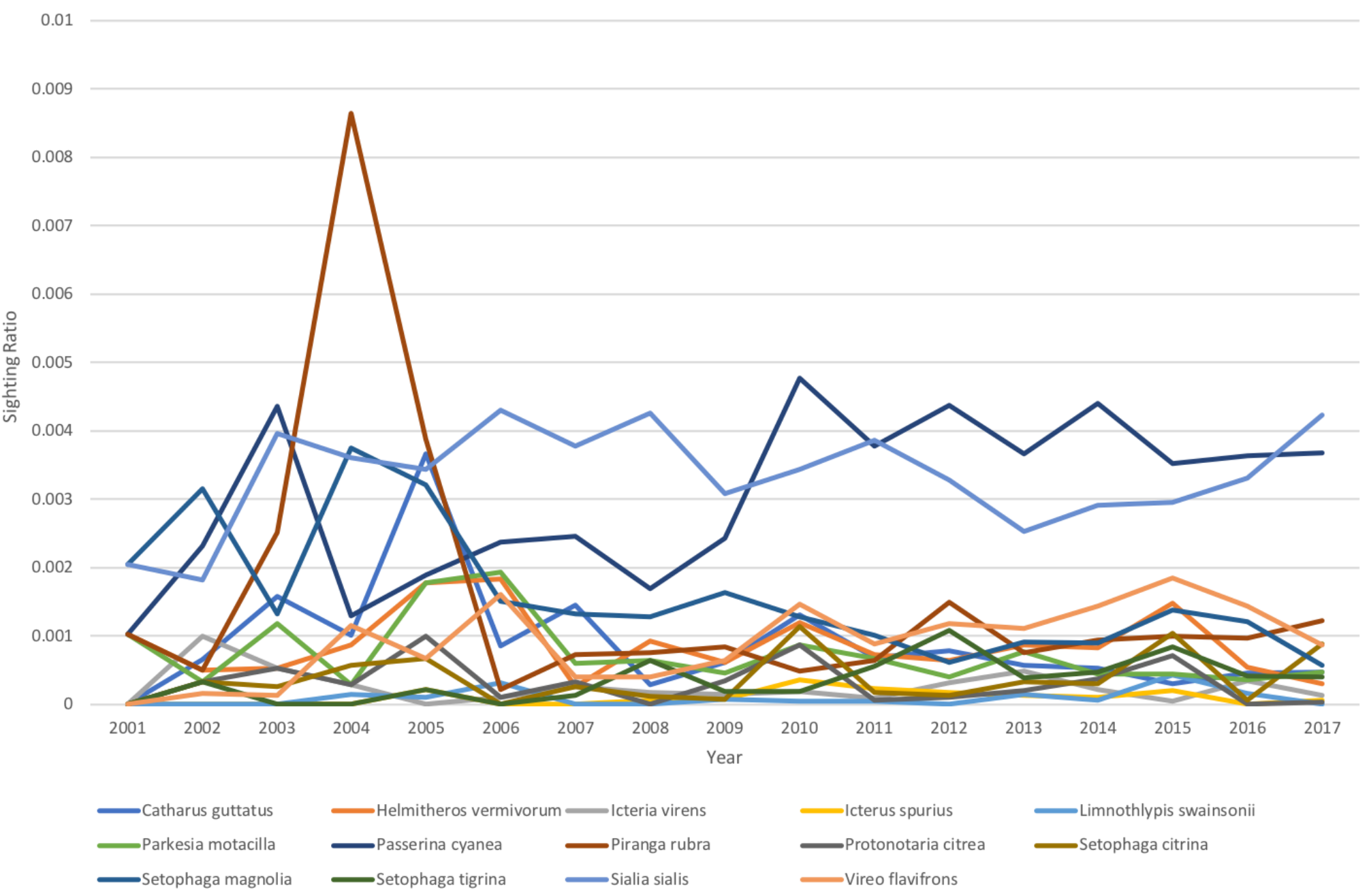

Figure 6: Target Species Sightings Ratios. Depicts the frequencies of target species sightings in south Florida (2001-2017). 

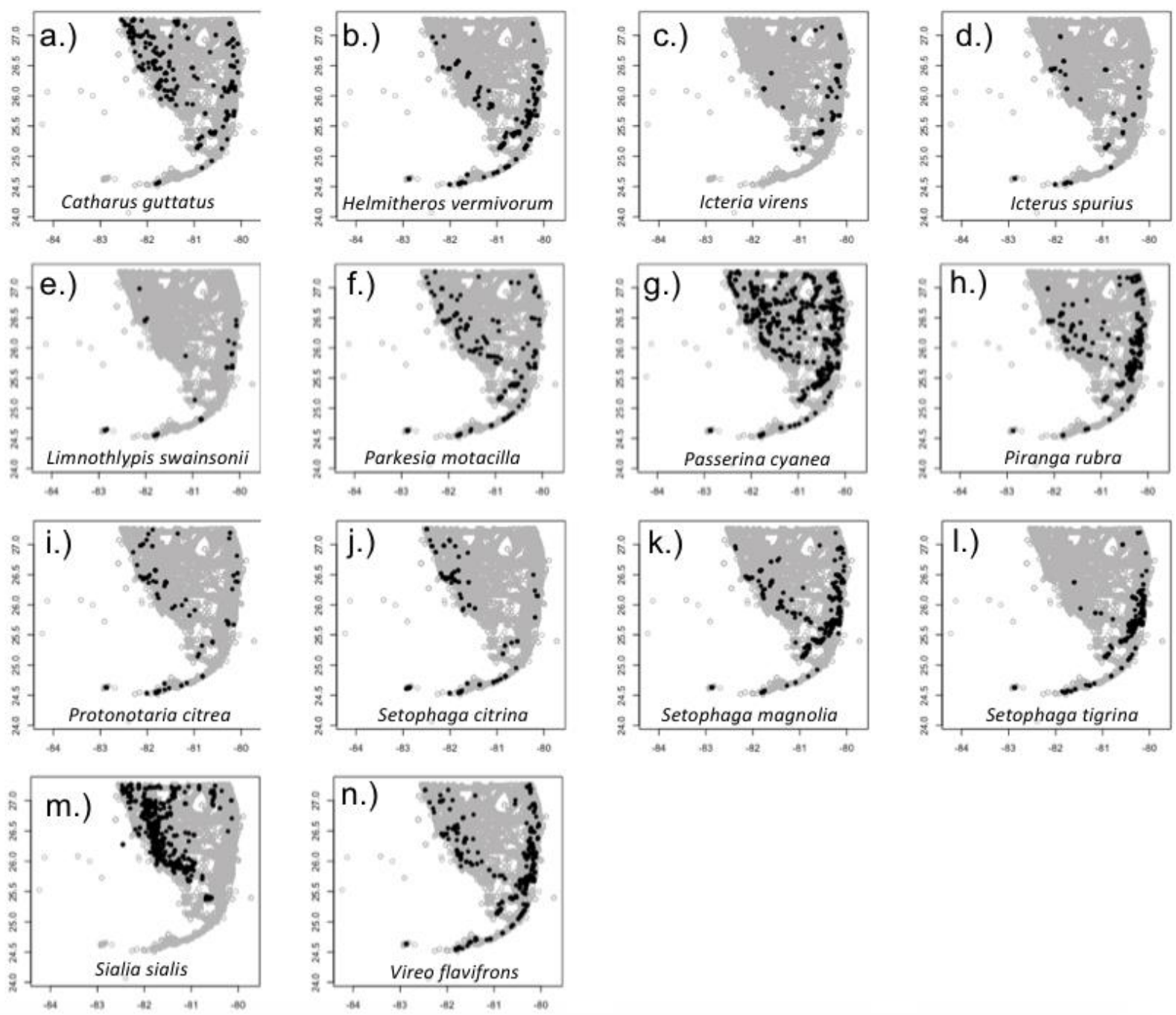

Figure 7: Target Species Sightings Maps. Depicts locations of each target species sighting (2001-2017) in black. Gray points represent all other species, 